\title{
Heavy-mineral assemblages from fluvial Pleniglacial deposits of the Piotrków Plateau and the Holy Cross Mountains - a comparative study
}

\author{
Lucyna Wachecka-Kotkowska' ${ }^{1}$ Małgorzata Ludwikowska-Kędzia ${ }^{2}$ \\ ${ }^{1}$ Department of Geomorphology and Palaeogeography, Faculty of Geographical Sciences, University of Łódź, Poland; \\ e-mail: kotkow@geo.uni.lodz.pl \\ ${ }^{2}$ Department of Palaeogeography, Geoecology and Nature Protection, Institute of Geography, \\ Jan Kochanowski University, Kielce, Poland; e-mail: mlud@pu.kielce.pl
}

\begin{abstract}
The heavy-mineral assemblages of Pleniglacial fluvial sediments were analysed for two river valleys, viz. the Luciąża River (at Kłudzice Nowe) and the Belnianka River (at Słopiec). These sites, on the Piotrków Plateau and in the Holy Cross Mountains respectively, are located in different morphogenetic zones of Poland that were affected to different degrees by the Middle Polish ice sheets. The study was aimed at determining the kind of processes that modified the heavy-mineral assemblages in the two fluvial sediments, at reconstructing the conditions under which these processes took place, and in how far these processes caused changes in the assemblages. The heavy-mineral associations of the parent material was taken as a starting point; this parent material were the sediments left by the Odranian glaciation (Warta stadial=LateSaalian). It was found that heavy-mineral assemblages in the Luciąża valley deposits are varied, particularly if compared with other fluvioglacial Quaternary deposits from the Polish lowlands, with a dominance of garnet. In the fluvial deposits of the Belnianka valley, zircon, staurolite and tourmaline dominate, with minor amounts of amphibole, pyroxene, biotite and garnet. This suggests that the deposits were subject to intensive and/or persistent chemical weathering and underwent several sedimentation/erosion cycles under periglacial conditions. In both valleys chemical weathering and aeolian processes were the main factors that modified the assemblages of the transparent heavy minerals; these processes were largely controlled by the climatic changes during the Pleistocene.
\end{abstract}

Key words: heavy-mineral analysis, fluvial deposits, Vistulian, Pleniglacial, central Poland, Holy Cross Mountains, Piotrków Plateau

\section{Introduction}

The initial mineral composition of a fluvial sediment undergoes numerous modifications, eventually changing the assemblages inherited from the source materials into a mineral assemblage of its own (e.g. Cordier et al., 2004; Weltje \& Von Eynatten, 2004; Scheiderman \& Chen, 2007; Thamo-Bozso \& Kovacs, 2007; Yang et al., 2009). Analysis of the heavy-mineral assemblage of fluvial deposits can help to recon- struct palaeogeographic changes (Van Loon, 1972/1973), to determine the character of the fluvial processes (Weckwerth \& Chabowski, 2013) and of the depositional environment (Thamo-Bozso \& Kovacs, 2007). This becomes difficult, however, when the material is derived from different sedimentological environments, for instance if a fluvial valley becomes invaded by an ice-sheet carrying material from several remote areas (Racinowski, 2008, 2010). Insight into the initial mineralogical composi- 
tion of the source material is therefore of utmost importance for the analysis of changes in the heavy-mineral composition of fluvial sediments during transport and after deposition. Neglecting this aspect may lead to misinterpretations of the modification processes and their effects (Batemann \& Catt, 2007).

Three provinces can be distinguished in Quaternary sediments of Poland on the basis of their mineral content; the differences in the mineral content depend on the extent of the Pleistocene ice sheets and on the exposure of pre-Quaternary rocks (Racinowski, 2008). The first province, with a well recognisable mineral composition, comprises the northern areas of the country (lakelands and lowlands), which are almost completely covered by glacial and fluvioglacial sediments with a mineralogy inherited from the Scandinavian source rocks (see also Woronko et al., 2013). The second province is constituted of highlands and old mountains with surficial pre-Quaternary rocks covered in the past by Scandinavian ice sheets, where the minerals originate from both glacigenic sediments and the substratum. The recognition of the various sources of the various mineral assemblages is difficult. The third province comprises the areas that were not covered by Scandinavian ice sheets, i.e. the Carpathians and the Sudetes, where the minerals originate only from the substratum and form well recognisable assemblages.

Racinowski (2010) claims that the source material of Pleistocene clayey tills and sandy/ gravely sediments, whatever their genetic and historical background, have a similar mineralogy, determined by the Scandinavian material that was transported and deposited by the ice sheets. The origin and lithostratigraphy of Quaternary deposits can consequently not be reconstructed unambiguously; the mineral assemblages can at best support other results of textural or structural analyses. It is therefore important to unravel how heavy-mineral assemblages can be affected by the various processes in different depositional environments.

\section{Objectives}

The objective of the present study was to analyse the heavy-mineral assemblages in the Pleniglacial (Vistulian, North Polish Complex, Weichselian, MIS 3-2) fluvial sediments of the Luciąża and Belnianka River valleys (Table 1), which represent valleys of the same order, but which are situated in different morphogenetic zones of Poland (Starkel, 2008). The Luciąża basin is located in the Eódź region - of the Polish Lowland (an old glaciated zone), and the Belnianka River runs in the Holy Cross Mountains (highlands and old mountains) (Fig. 1B).

The Pleniglacial deposits of both rivers indicate a similarity in structure and also in some textural features (Wachecka-Kotkowska \& Ludwikowska-Kędzia, 2007). The analyses of the Pleniglacial sediments should therefore show whether it is possible to unravel how, and in how far, modification processes affected the heavy-mineral assemblages of the flu-

Table 1. Comparison of the geomorphological and lithological features in the Luciąża and the Belnianka River valleys.

\begin{tabular}{|c|c|c|}
\hline & Similarities & Differences \\
\hline \multirow{2}{*}{$\begin{array}{l}\text { Teracces/ } \\
\text { river levels }\end{array}$} & \multirow{2}{*}{$\begin{array}{l}\text { the Pleniglacial erosion/accumulation } \\
\text { levels originated at the same time and } \\
\text { under periglacial conditions }\end{array}$} & valley developed on: \\
\hline & & $\begin{array}{c}\text { a Palaeozoic substratum } \\
\text { (Belnianka) }\end{array} \begin{array}{c}\text { Wartanian (Saalian) glacial } \\
\text { surface (Luciąża) }\end{array}$ \\
\hline \multirow[t]{2}{*}{ Deposits } & $\begin{array}{l}\text { both deposits consist of two parts, } \\
\text { separated by an erosional surface: } \\
\text { a silty/sandy lower part and } \\
\text { a sandy top part; } \\
\text { thickness up to } 18 \mathrm{~m}\end{array}$ & $\begin{array}{l}\text { different thicknesses; proportions depending on local } \\
\text { conditions (widening/narrowing of the valleys) }\end{array}$ \\
\hline & $\begin{array}{l}\text { several genetic processes involved } \\
\text { (fluvial, slope, aeolian); } \\
\text { fluvioperiglacial cover }\end{array}$ & $\begin{array}{l}\text { various proportions of deposits of different origin, } \\
\text { depending on local conditions }\end{array}$ \\
\hline
\end{tabular}



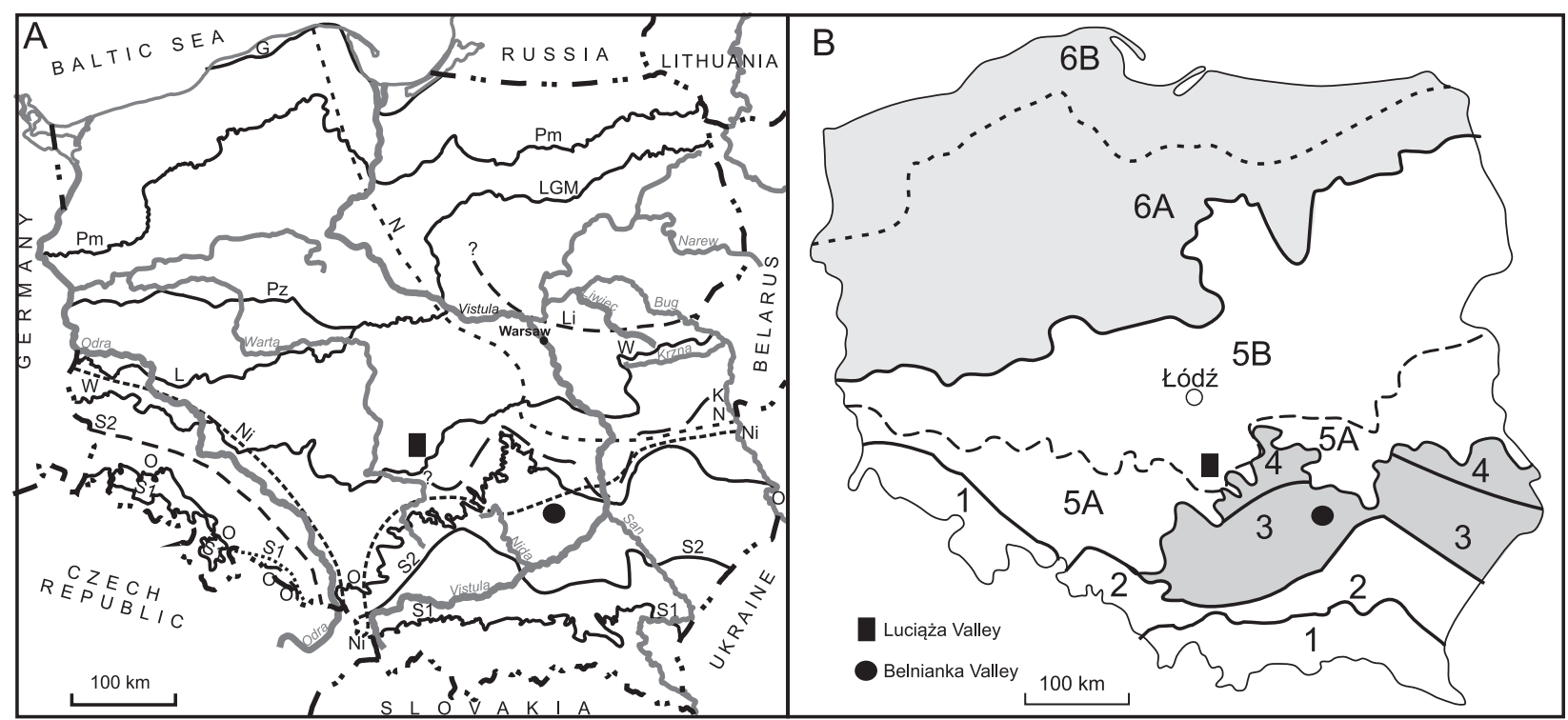

Fig. 1. Location of the study area.

A: Maximum extent of Pleistocene glaciations in Poland (after Marks, 2011). Early Pleistocene: $\mathrm{N}=\mathrm{Narewian}(=$ Menapian), $\mathrm{Ni}=$ Nidanian (= Cromerian complex, Glacial A); Middle Pleistocene: $\mathrm{S1}$ = Sanian 1 (= Cromerian complex, Glacial B), S2 = Sanian (= Elsterian) 2, Li = Liwiecian (= Saalian, Fuhne), K = Krznanian (= Saalian, glacial episode in Poland, $\mathrm{O}=$ Odranian with secondary stadial of $\mathrm{W}=$ Wartanian (= Saalian, Drenthe, Warthe); Late Pleistocene: Vistulian (= Weichselian), with LGM = Last Glacial Maximum, L = Leszno phase, Pz = Poznań phase, Pm = Pomeranian phase, $\mathrm{G}=$ Gardno phase.

B: Morphogenetic zones (modified after Gilewska, 1991; Starkel, 2008). 1 = mountains; 2 = intramontaneous basins; 3 = uplands and old mountains; $4=$ transitional area of upland/old-glacial relief; $5 \mathrm{a}=$ area glaciated before the Wartanian (MIS 6, Late Saalian); 5b = area glaciated during the Wartanian; 6a = area glaciated during earlier stages of the Vistulian (= Weichselian, MIS 2) (with outwash plains); $6 \mathrm{~b}=$ area covered by ice during the Pomeranian phase of the Vistulian.

vial deposits in the two river valleys that have a different background regarding their morphology and glaciation history.

\section{Methods}

Transparent heavy minerals from the above fluvial sediments were analysed for the 100$250 \mu \mathrm{m}$ fraction, using standard samples of $\sim 700$ grains, of which $\sim 300$ were transparent. Bromoform was used as a separation liquid. From the Kłudzice Nowe profile in the Luciąża River valley, 10 samples were analysed (Table 2), whereas 18 samples from the Słopiec Szlachecki profile near Daleszyce in the Belnianka river valley were analysed (Table 3 ).

The results were compared with the heavy-mineral assemblages from Wartanian deposits in both river valleys (15 samples) that formed the local source material for the Pleniglacial sediments under study; the results were also compared with the mean content of the main transparent heavy minerals in Quaternary deposits in Poland (Table 4) as analysed by Racinowski (2010).

For each sample, the weathering index (WI) was calculated following Racinowski \& Rzechowski (1969) (see also Mycielska-Dowgiałło, 1995, 2007; Ludwikowska, 2013; Marcinkowski \& Mycielska-Dowgiałło, 2013):

$$
\mathrm{W}=(\mathrm{SR} / \mathrm{R}) \mathrm{NR}
$$

where $\mathrm{W}=$ weathering index, $\mathrm{SR}=$ percentage of semi-resistant minerals (apatite, epidote, garnet, sillimanite), $\mathrm{R}=$ percentage of resistant minerals (zircon, rutile, tourmaline, staurolite, kyanite), and NR = percentage of non-resistant minerals (amphibole, pyroxene, biotite, chlorite).

This formula describes the transformation of the heavy-mineral assemblage as a result of weathering. 


\section{Study areas}

As the study is aimed at assessing differences in fluvial heavy-mineral assemblages as a result of differences in source material and local conditions, these aspects are dealt with in the following sections.

\subsection{Locations}

The Luciąża River valley is located in central Poland, SE of the Łódź region (Turkowska, 2006), on the border of the Polish Lowland and Highland (1.7\%o stream gradient). The Luciąża river starts at $245 \mathrm{~m}$ a.s.l., at the foot of the Góra Chełmo (323 m a.s.l.) in the Radomsko Hills area (Przedbórz Highland, part of the Polish Highland). After $48 \mathrm{~km}$, it flows into the Pilica River (Vistula basin), on the Piotrków Plateau (Mazovia Lowland, part of the Polish Lowland) at $166 \mathrm{~m}$ a.s.l. The average height of the catchment area is ca $200 \mathrm{~m}$ a.s.l.

The Belnianka River valley is a typical small valley, situated in the central part of the Holy Cross Mountains. Its length is $34 \mathrm{~km}(11.04 \%$ o stream gradient) and its springs are located at $455.23 \mathrm{~m}$ a.s.l., on the southern slope of the
Łysogóry range (612.3 $\mathrm{m}$ a.s.l.). It enters the Lubrzanka River at $235.2 \mathrm{~m}$ a.s.l. The average height of the catchment area is $316.25 \mathrm{~m}$ a.s.l., indicating an upland character.

Both the Belnianka and the Luciąża Rivers occupy third-order valleys that belong to the Nida basin and Pilica basin respectively (Vistula $1^{\text {st }}$ order basin). Both valleys are situated in the periglacial zone of the last ice sheet (Fig. 1A): the Luciąża basin is located approx. 150$200 \mathrm{~km}$ away from the line indicating the ice extent during the Last Glacial Maximum line (LGM), whereas this is approx. $300 \mathrm{~km}$ for the Belnianka basin. Their distances to the maximum ice extent during the Odranian Warta stadial are different: the pre-Belnianka valley was situated in the periglacial zone of the Wartanian ice sheet, whereas the pre-Luciąża valley was overridden by it (Fig. 1A).

\subsection{Geology and geomorphology}

The base of the Vistulian pre-Luciąża valley consists of deposits that accumulated during the Middle Polish Complex (MIS 6, Late Saalian, Odra glaciation, Warta stadial) (Fig. 2). The retreat of the Wartanian ice sheet led to

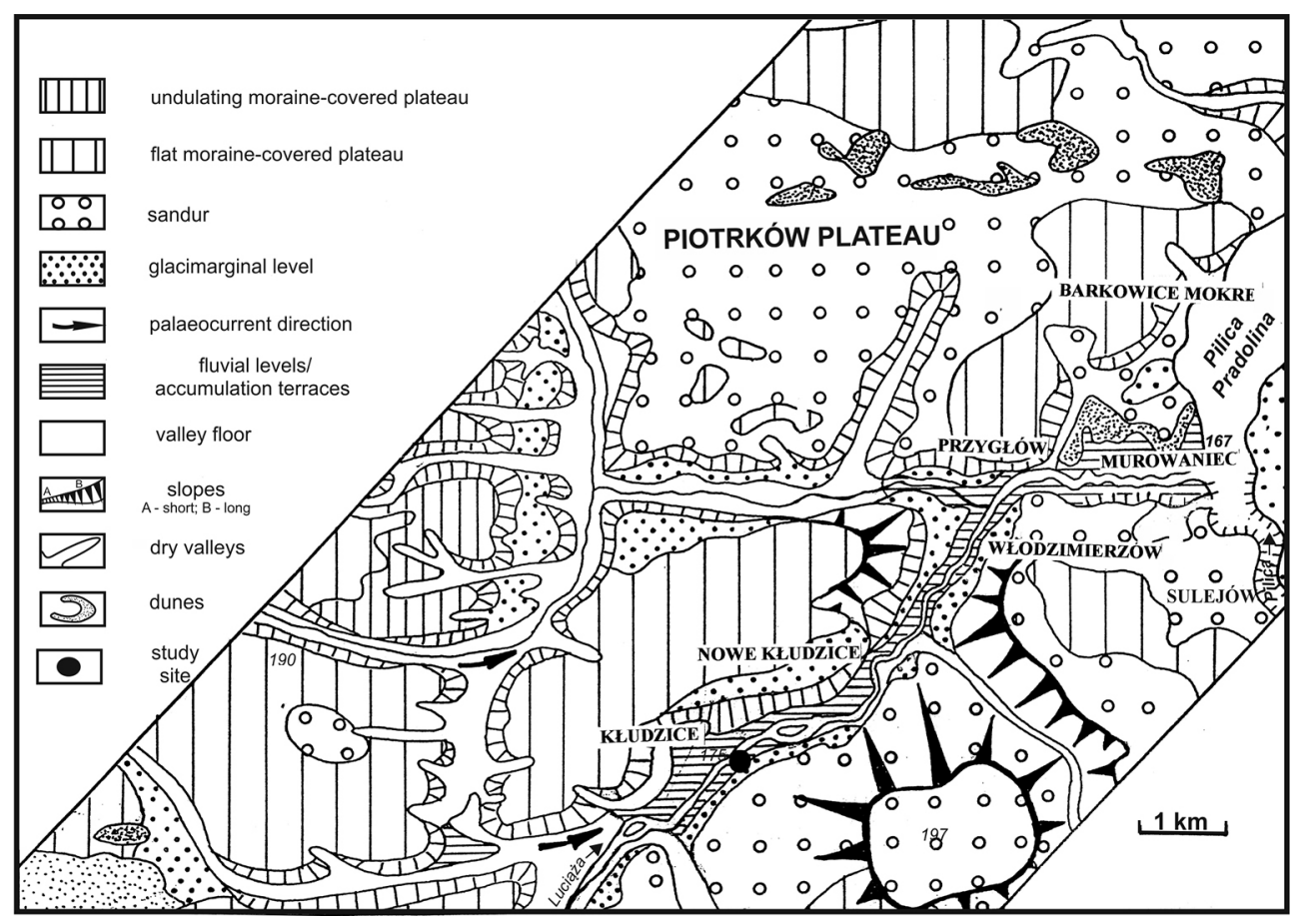

Fig. 2. Schematic geomorphology of the lower Luciąża River valley. 
the formation of two separate valleys, an upper one directed to the south and a lower one to the north; both are associated with glaciomarginal outwashes, often along the valleys of the time, on fault lines (Wachecka-Kotkowska, 2006). The glaciomarginal $3^{\text {rd }}$ level at $10-15 \mathrm{~m}$ above the valley floor developed during the glacial episode. During the early Pleniglacial, the Dobryszyckie Hills (Wartanian morainic hillocks) in the middle part of the area became incised; a single valley, similar to the present, then originated because two small valleys became interconnected (Wachecka-Kotkowska, 2004). The Vistulian elements are the $2^{\text {nd }}$ (high) level/terrace (Pleniglacial; $2-6 \mathrm{~m}$ above the valley floor) and the $1^{\text {st }}$ (low) fluvial terrace (Late Vistulian, 1.5-2 $\mathrm{m}$ above the valley floor).

The Belnianka River valley lies in the central part of the Palaeozoic core of the Holy Cross Mountains, where the present-day relief strictly reflects the geology (Wróblewski, 1977; Ludwikowska-Kędzia, 2000). The area consists of alternating expansion zones (often with river basins) and narrowings (gaps, with Palaeogene-Neogene bases) (Ludwikowska-Kędzia, 2000). This is particularly visible in the fragment of the valley within the Chęciny-Kli- montów anticlinal zone and the area of Smyków-Słopiec Szlachecki (Fig. 3).

The relief and the Quaternary sediments of the Belnianka River, which owe their characteristics to the glacial cycle, have been strongly transformed by denudation under periglacial conditions, particularly after the disappearance of the Sanian 2 ice sheet (South Polish Complex, Elsterian). In the section of the valley under study, three to four terrace levels can be distinguished. The level of middle Pleniglacial accumulation (260 $\mathrm{m}$ a.s.l.; $2.5-10 \mathrm{~m}$ above the valley floor) is exposed in a 10-m profile where erosion undercut the Belnianka River near Słopiec Szlachecki. The profile is representative and allows a palaeogeographical reconstruction of the valley. The middle Pleniglacial erosional and erosional/accumulation lower terraces (250-258 m a.s.l.; $1.2-2 \mathrm{~m}$ above the valley floor) are locally present, among other places in the vicinity of Niwy Daleszyckie. They are usually adjacent to the Holocene terrace and are locally covered by Holocene fluvial sediments. The Pleniglacial level and terraces are asymmetrical in the Belnianka river valley section under study. The right level terrace (Słopiec profile) has probably been elevated tectonically and takes a larger area.

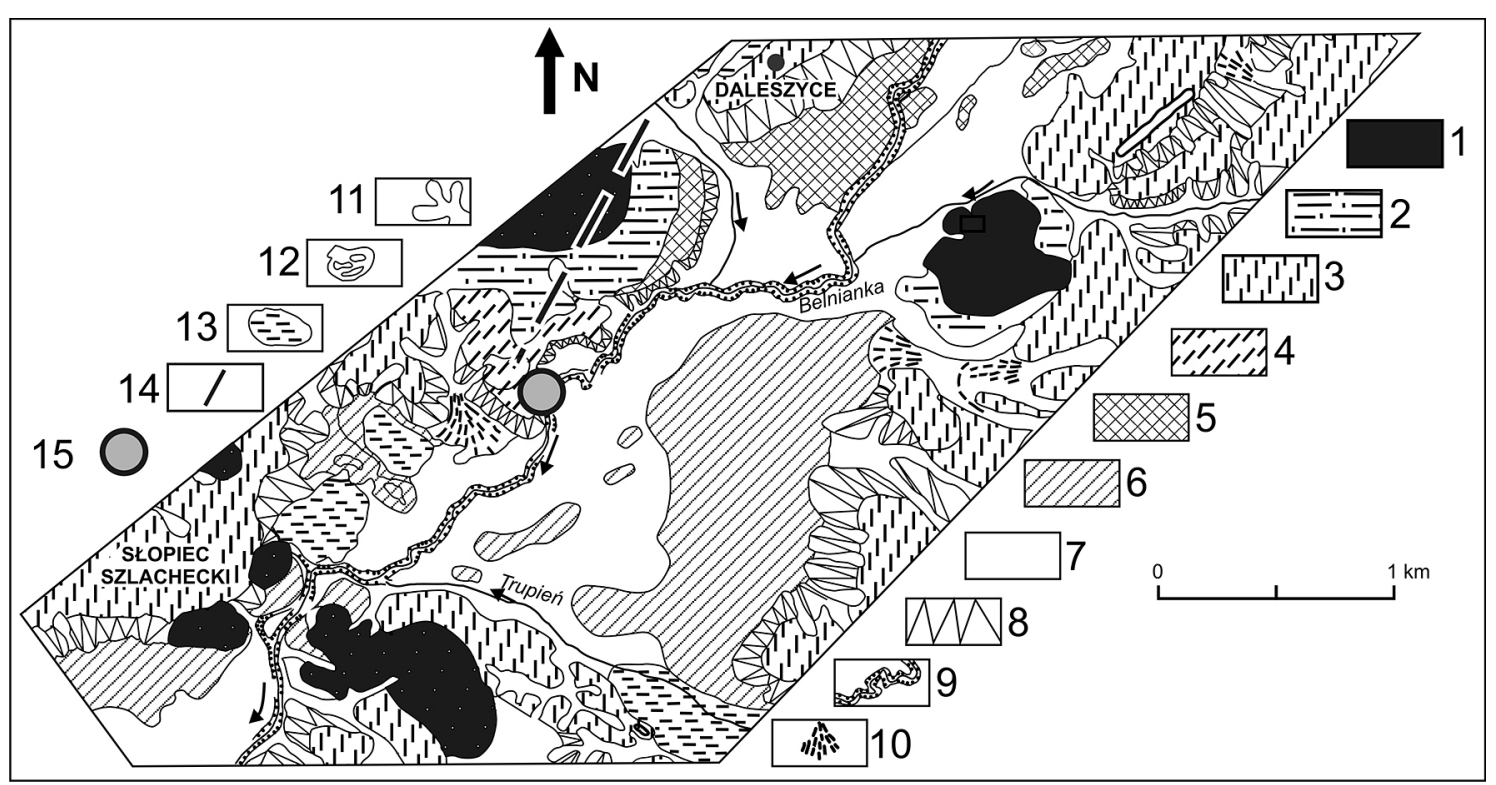

Fig. 3. Schematic geomorphology of the middle Belnianka River valley.

1 = Palaeozoic bedrock; 2 = denudation surface within slope deposits; 3 = Middle-Polish glaciation levels; 4 = Middle Pleniglacial accumulation terraces; 5 = Middle Pleniglacial erosional terraces; $6=$ Late Vistulian accumulation terraces; $7=$ Holocene valley floor; $8=$ slopes of terraces; $9=$ river bed; $10=$ alluvial fans; $11=$ denudation valleys; 12 = dunes; 13 = peatbog; 14 = fault; 15 = Słopiec profile. 
A sedimentological characteristics

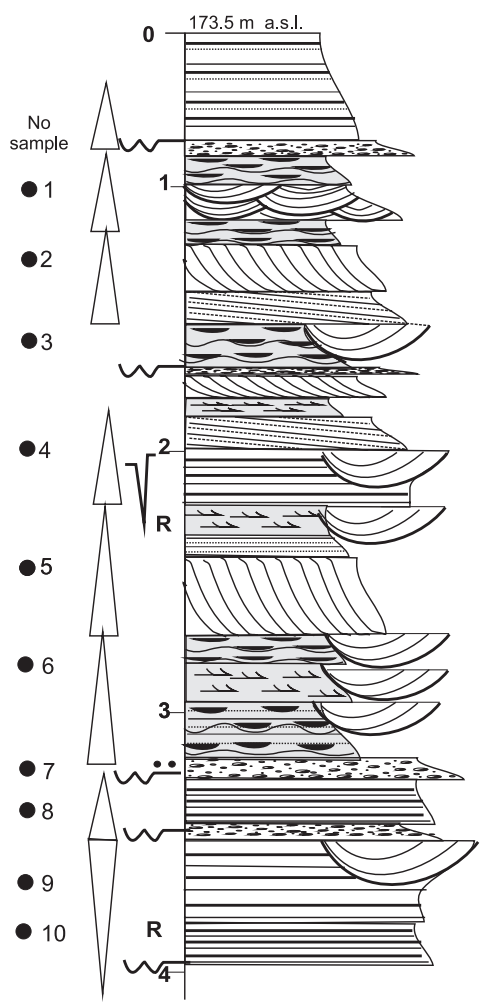

- 11(see: Tab. 2)

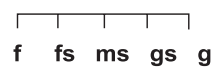

\section{D}

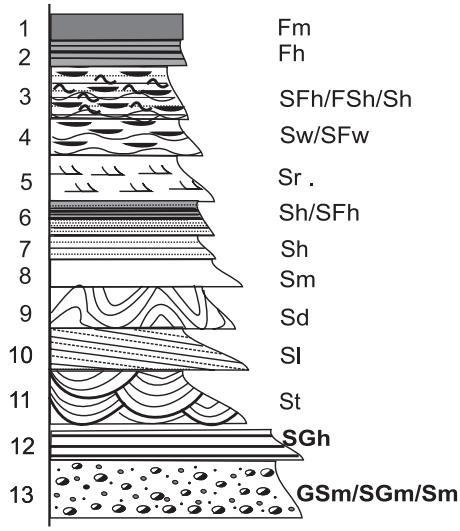

lithofacies

Sh

Sw/SFw

St

Sw/SFw

Sp

SI

Sw/St

SGm

Sp

SI

Sh/St

St

Sp

Sw/St

Sr/SFr

Sw/Sh

SGh/Sh

SGm

SGh/St

SGh/Sh

14

15 def

$16 \sim^{\bullet}$

$17 \sim$

$18 \sqrt{ }$

$19 \mathbf{R}$
B

heavy-mineral composition

C weathering index

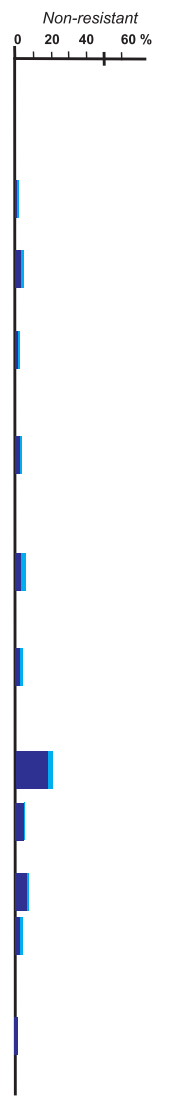

Semi-resistant
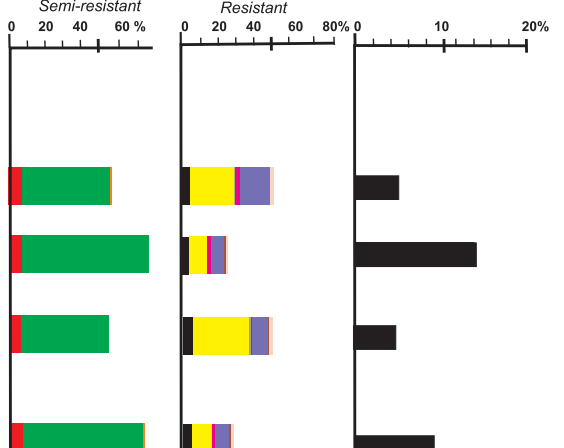

Amphiboles
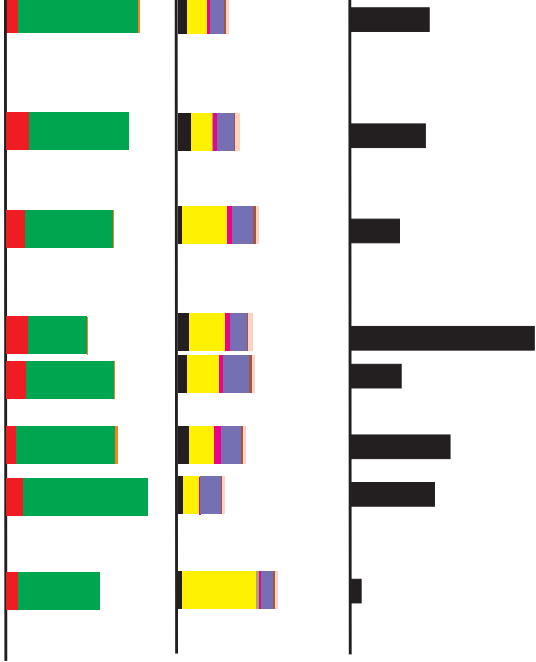

Pyroxenes

Epidotes

Tourmalines Kyanite Others

Zircons

Staurolite

Chlorites/Biotites Sillimanite

Rutiles

Andalusite

Fig. 4. Some features of the Pleniglacial sediments at the Kłudzice Nowe profile in the lower Luciąża River valley.

A: Sedimentological characteristics; B: heavy-mineral composition; C: weathering index after Racinowski \& Rzechowski (1969); D: codes after Miall (1978, 1985), as modified by Zieliński \& Pisarska-Jamroży (2012): $1=$ massive silt; 2 = horizontally laminated silt; $3=$ silty sand, silt and sandy silt with horizontal lamination; $4=$ silty sand, silt and sandy silt with flasers; $5=$ ripple-cross laminated sand and sandy silt; $6=$ sand, sandy silt and silty sand with horizontal lamination; $7=$ sand with horizontal lamination; $8=$ massive sand; $9=$ deformed sand; $10=$ low-angle cross-stratified sand; $11=$ through cross-bedded sand; 12 = gravelly sand with horizontal stratification; $13=$ massive gravely sand and sandy gravel; 14 = fining- and coarsening-upward sequence; $15=$ deformations; $16=$ erosional contact; 17 = large-scale erosional surface; 18 = ice-wedge cast; 19 = rhythmite. 


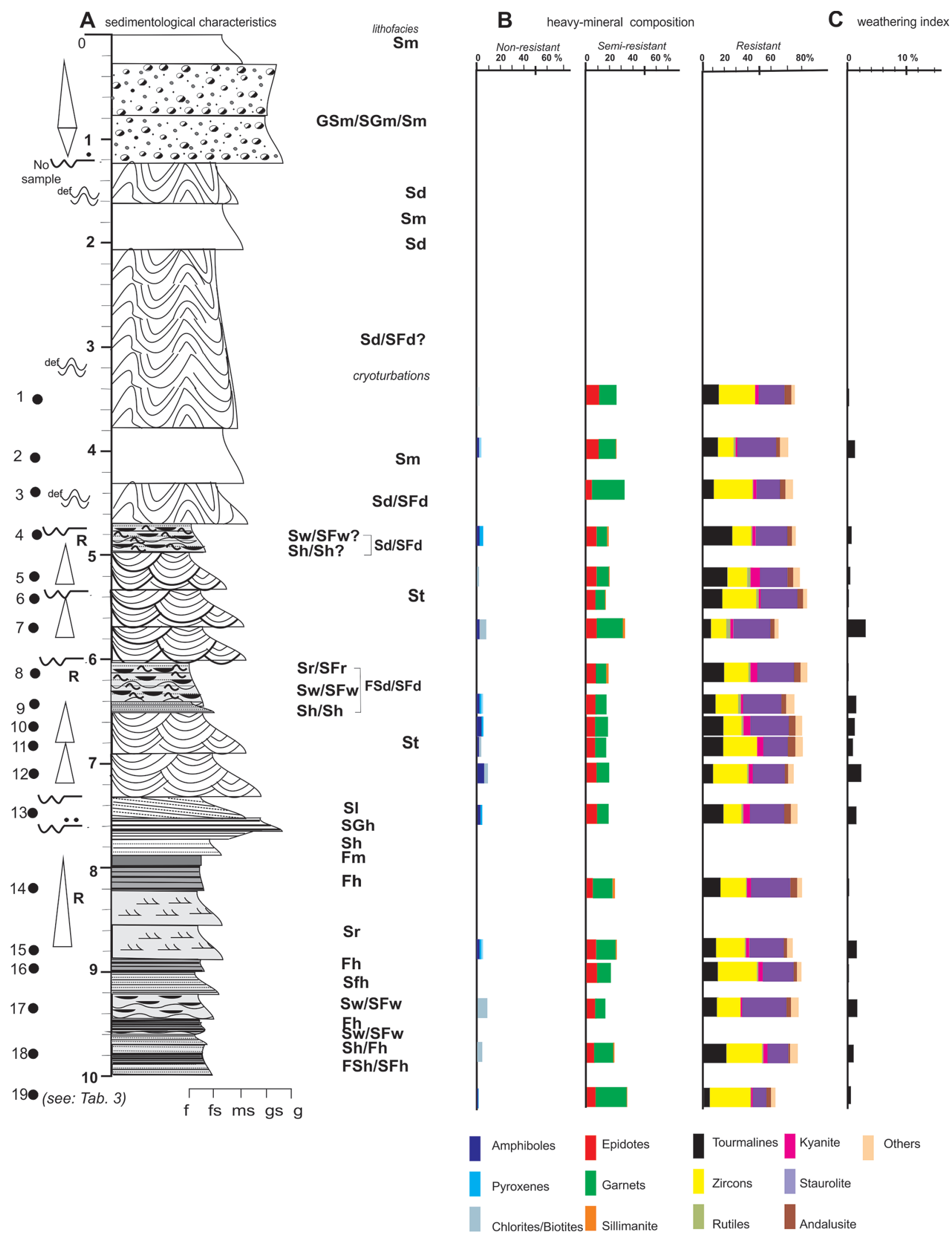

Fig. 5. Some features of the Pleniglacial sediments at the Słopiec Szlachecki profile in the middle Belnianka River valley (for explanations, see Fig. 4). 


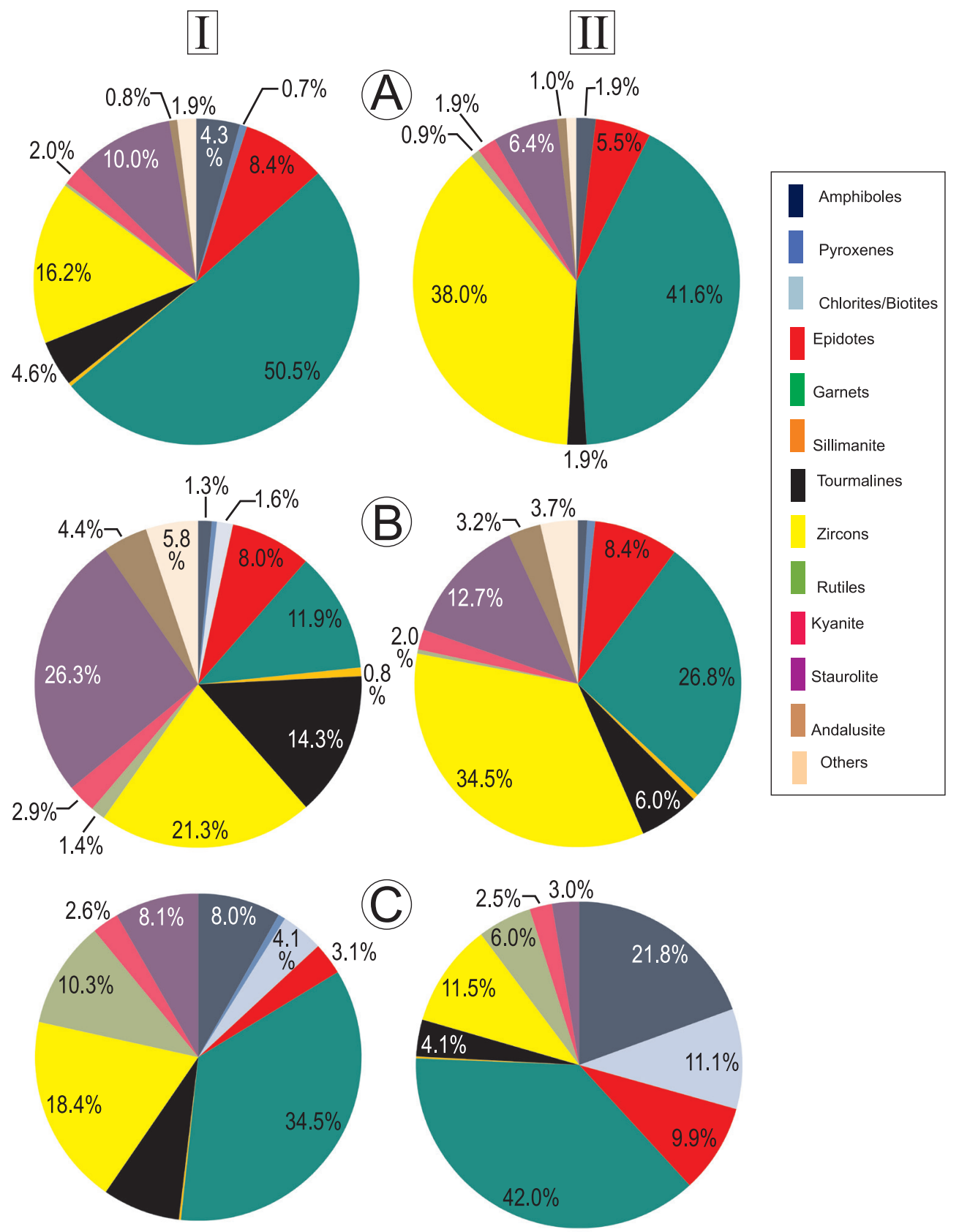

Fig. 6. Mean composition of the transparent heavy minerals of the Luciąża valley (A) and Belnianka valley (B) and of the Vistulian valleys in northern Poland (C) after Racinowski (2010).

$\mathrm{I}=$ alluvium; II = basement of the Pleniglacial alluvium.

Detailed investigations of the Pleniglacial sediments were carried out at Kłudzice Nowe. That site is located in the lower, narrow part of the Luciąża River valley, in a meander undercut of the $2^{\text {nd }}$ high level near Przygłów (5 $\mathrm{km}$ NE of Sulejów), where sediments were encountered to a depth of $3.5 \mathrm{~m}$ (Fig. 2). For comparison with the Luciąża River valley, a 10-m exposure was chosen in the erosional undercut of the Belnianka valley level (named 'high terrace' after Łyczewska, 1971) at Słopiec Szlachecki near Daleszyce (Fig. 3).

\subsection{Characteristics of the Pleniglacial sediments}

The similarity of the structural and textural characteristics of the sediments building the terraces in the river valleys of the periglacial 
uplands and lowlands is clear from the example of the Luciąża and Belnianka Rivers (Table 1; Figs 4, 5). In both valleys, the fluvial sediments are characterised in their vertical profiles by repeated phases of accumulation and a duality in the succession of the deposits (Ludwikowska-Kędzia, 2007; Wachecka-Kotkowska, 2007; Wachecka-Kotkowska \& Ludwikowska-Kędzia, 2007). The lower profiles are represented by middle Pleniglacial finer deposits, a silty/ sandy unit $(\mathrm{Mz}=4-7 \Phi)$, badly and extremely badly sorted material $\left(\sigma_{1}=1.27-2.82\right)$, accumulated in a low-energy environment $\left(\mathrm{Sk}_{1}=0.16-\right.$ 0.69). The main lithofacies, Fh, Sh, FSh and SFh (Figs 5, 6), indicate deposition in an overbank area and/or a shallow lake.

The upper part of the profiles occurs above an erosional surface that represents ice advance during the LGM (late Pleniglacial). The deposits of this upper part are built of sandy and sandy/gravely $(\mathrm{Mz}=1-2.5 \Phi)$, well sorted material $\left(\sigma_{1}=0.35-1\right)$ of a higher-energy depositional environment $\left(\mathrm{Sk}_{1}=-0.25-0.25\right)$ (Figs 5, 6). Lithofacies Sr, Sl, St and SGh are dominant (Wachecka-Kotkowska \& Ludwikowska-Kędzia, 2007). Upwards in the profile, the thicknesses of the sandy units increase.

The abrasion of the quartz grains (see Woronko, 2012) in the lower part of the profiles differs from that in the upper part: rounded matt grains constitute $70-80 \%$ in the upper part, whereas this value is $45-60 \%$ in the lower part (Mycielska-Dowgiałło, 2001; Wachecka-Kotkowska \& Ludwikowska-Kędzia, 2007). Cryogenic and unstable stratification structures (thermoturbations and instabiloturbations sensu Van Loon, 2009, respectively) are common (Fig. 4). The deposits of the terraces were accumulated by means of several processes (fluvial, slope and aeolian); for this reason they are commonly named 'valley levels', so as to distinguish them from the younger, late Vistulian sediments, building fluvial terraces. The similarity of the middle Pleniglacial structural and textural features of the sediments of the valley levels of both the upland and lowland periglacial rivers results from the climatic conditions, which determined vectors, intensity and type of the depositional and geomorphological processes in the valleys.

\section{Heavy-mineral composition}

As mentioned above, the Wartanian glacial, fluvioglacial and proglacial (periglacial) sediments in the regions of both study areas formed the source of the Pleniglacial fluvial deposits under study. The Pleniglacial sediments thus inherited their heavy-mineral assemblages from the Wartanian sediments, the heavy-mineral assemblages of which were therefore also investigated for the present study.

\subsection{Wartanian glacial/fluvioglacial and periglacial sediments}

Glacial and fluvioglacial deposits of the Middle Polish Complex (MIS 6, Late Saalian, Odranian glaciation, Warta stadial) form the substratum of the Luciąża valley. The Pleniglacial fluvial level in this valley is therefore in its lower part mixed up with Wartanian fluvioglacial deposits that originated during a phase of retreat of the Odranian ice sheet. At the time meltwater flowed to the Pilica pradolina, and in the lower Luciąża valley the Wartanian glaciomarginal $3^{\text {rd }}$ level came into being (Fig. 2).

At the Kłudzice Nowe site, only one sample from the Wartanian basement (see Fig. 2) was collected for heavy-mineral analysis. The heavy-mineral assemblage shows (Table 2, Figs 4,6 ) an equilibrium between the semi-resistant (41.6\% garnet, $5.5 \%$ epidote) and the resistant minerals (38\% zircon, 6.4\% staurolite, $1.9 \%$ kyanite, $1.9 \%$ tourmaline, $0.9 \%$ rutile and $0.9 \%$ andalusite). Non-resistant minerals are less common (only 1.9\% amphibole). It proves that local, old sediments, not only of Pleistocene age, were reworked, transformed during transport and sedimentation in a glacial or fluvioglacial environment. They were subsequently exposed to (chemical) weathered during the Eemian and early Vistulian under different climatic conditions (from warmer to colder).

The basement of the Pleniglacial fluvial sediments of the Belnianka valley level at Słopiec Szlachecki contains slope deposits of the Bielińskie range, formed under periglacial conditions. Their accumulation took place during 
Table 2. Heavy minerals of the Pleniglacial alluvium of the Luciąża valley in the Nowe Kłudzice profile (see also Figs $4,6 \mathrm{~A})$.

\begin{tabular}{|c|c|c|c|c|c|c|c|c|c|c|c|}
\hline Sample number & 1 & 2 & 3 & 4 & 5 & 6 & 7 & 8 & 9 & 10 & $11^{*}$ \\
\hline Number of grains & 528 & 570 & 577 & 475 & 488 & 552 & 484 & 470 & 558 & 592 & 570 \\
\hline Opaque heavy minerals ( $\%)$ & 35.6 & 39.5 & 42.9 & 32.6 & 40.4 & 48.4 & 31.6 & 36.2 & 38.2 & 42.2 & 43.2 \\
\hline glauconite & 0 & 0 & 0 & 0 & 0 & 0 & 0 & 0 & 0 & 0 & 0 \\
\hline carbonate & 0 & 0 & 0 & 0 & 0 & 0 & 0 & 0 & 0 & 0 & 0 \\
\hline $\begin{array}{l}\text { Transparent } \\
\text { heavy minerals (\%) }\end{array}$ & 64.4 & 60.5 & 57.1 & 67.4 & 59.6 & 51.6 & 68.4 & 63.8 & 61.8 & 57.8 & 56.8 \\
\hline \multicolumn{12}{|c|}{ Transparent heavy minerals (total calculated as $100 \%$ ) } \\
\hline amphibole & 1.5 & 3.5 & 1.3 & 2.7 & 2.6 & 2.8 & 16.6 & 4.0 & 5.8 & 2.3 & 1.9 \\
\hline pyroxene & 0.4 & 0.4 & 0.4 & 0.6 & 1.5 & 0.9 & 1.4 & 0.3 & 0.7 & 0.6 & 0 \\
\hline biotite & 0 & 0 & 0 & 0 & 0 & 0 & 0 & 0 & 0 & 0 & 0 \\
\hline chlorite & 0 & 0 & 0 & 0 & 0 & 0 & 0 & 0 & 0 & 0 & 0 \\
\hline epidote & 6.3 & 6.5 & 6.4 & 6.9 & 11.9 & 9.3 & 12.1 & 10.7 & 5.1 & 8.8 & 5.5 \\
\hline garnet & 44.1 & 63.6 & 45.3 & 62.6 & 51.1 & 44.9 & 30.2 & 45.3 & 52.2 & 63.8 & 41.7 \\
\hline tourmaline & 3.9 & 4.3 & 5.6 & 4.7 & 6.7 & 1.4 & 6.1 & 4.8 & 5.8 & 2.3 & 1.9 \\
\hline zircon & 22.6 & 9.6 & 29.2 & 10.9 & 10.8 & 23.4 & 18.1 & 16.0 & 13.0 & 8.2 & 38.0 \\
\hline rutile & 0.4 & 0.4 & 0.3 & 0.5 & 0.5 & 0.4 & 0.3 & 0 & 0 & 0 & 0.9 \\
\hline kyanite & 2.2 & 2.0 & 0.9 & 0.9 & 2.1 & 2.8 & 2.6 & 2.3 & 3.6 & 0.6 & 1.9 \\
\hline staurolite & 15.4 & 7.0 & 8.7 & 7.8 & 9.3 & 11.2 & 9.1 & 13.3 & 10.9 & 10.5 & 6.4 \\
\hline andalusite & 0.7 & 0.9 & 0.7 & 0.9 & 1.0 & 1.0 & 0.4 & 1.0 & 0.7 & 0.6 & 0.9 \\
\hline sillimanite & 0.7 & 0 & 0 & 0.6 & 0 & 0.5 & 0.4 & 0.3 & 1.1 & 0 & 0 \\
\hline other & 0 & 0.9 & 0.4 & 0.3 & 0.4 & 0 & 0.8 & 0.3 & 0.4 & 0.3 & 0 \\
\hline unidentified & 1.8 & 0.9 & 0.8 & 0.6 & 2.1 & 1.4 & 1.9 & 1.7 & 0.7 & 2.0 & 0.9 \\
\hline
\end{tabular}

* basement, fluvioglacial level according to Wachecka-Kotkowska, 2007; mean value.

the Warta stadial (MIS 6, late Saalian, Odranian glaciation) (Ludwikowska-Kędzia, 2007). The assemblages of the transparent heavy minerals in 14 samples show a dominance of zircon (21.2-63.7\%) and garnet (11.8-40.1\%; mean value $26.81 \%$ ) (Table 3; Figs 5, 6) (Ludwikowska-Kędzia, 2007). The zircon/garnet assembly is complemented by staurolite $(4.85-25.6 \%$; mean value $12.73 \%)$, epidote $(2.5-17.5 \%$; mean value $8.39 \%)$, tourmaline $(1.3-10.8 \%$; mean value $5.99 \%)$, andalusite $(1.9-7.7 \%$; mean value $3.2 \%)$ and kyanite $(1.0-10.7 \%$; mean value $2.0 \%$ ) (Fig. 6). No micas (biotite) were found, and the amounts of amphibole and pyroxene are negligible (mean values below 1\%). Abrasion-resistant minerals dominate (41.3-76.4\%; mean value $58.84 \%$ ). The medium-resistant minerals (18.9-52\%; mean value $35.76 \%$ ) constitute slightly less, and the non-resistant minerals take only a small percentage (1.0-4.2\%; mean value $1.36 \%$ ).

All abrasion-resistant minerals have rounded grains, which indicate, in combination with the high zircon percentage, that the material underwent numerous sedimentation/erosion cycles. The garnet grains are mostly colourless, surficially corroded, showing pits and other traces of chemical weathering (cf. Van Loon \& Mange, 2007). The high proportion of opaque minerals (34.3-79.7\%; mean value $48.35 \%$ ) proves that the material has been subjected to chemical weathering.

The above results suggest an environment in which the sediments underwent washing, aeolian activity, intensive chemical weathering and physical abrasion time and again. This is supported by the low values of the weathering index, which vary from 0.27 to 3.97 (Fig. 5) (Ludwikowska-Kędzia, 2007).

\subsection{Heavy minerals from the Pleniglacial fluvial deposits in the Luciąża valley}

The heavy-mineral assemblages in the sediments from the Kłudzice Nowe profile in the 


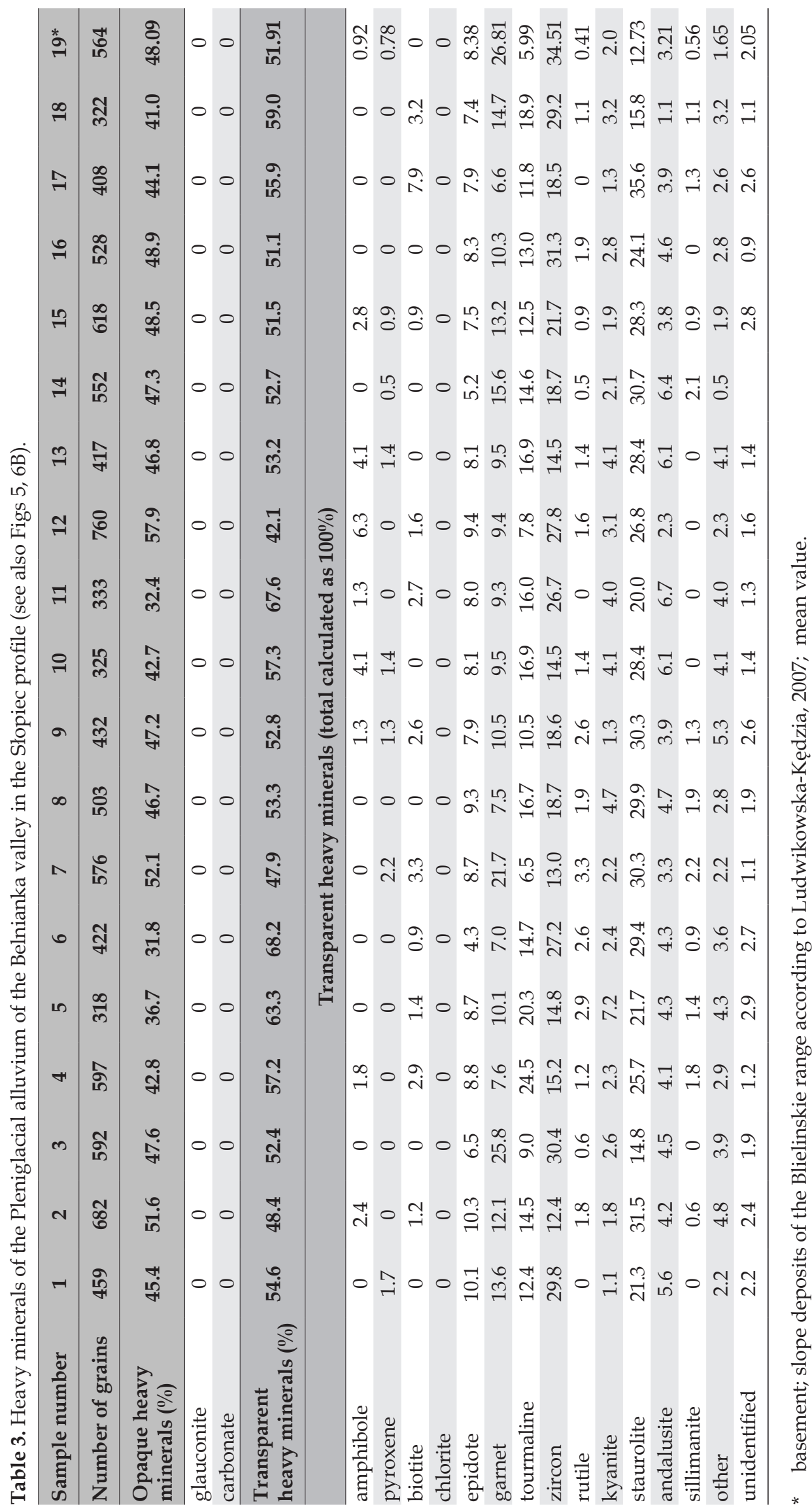




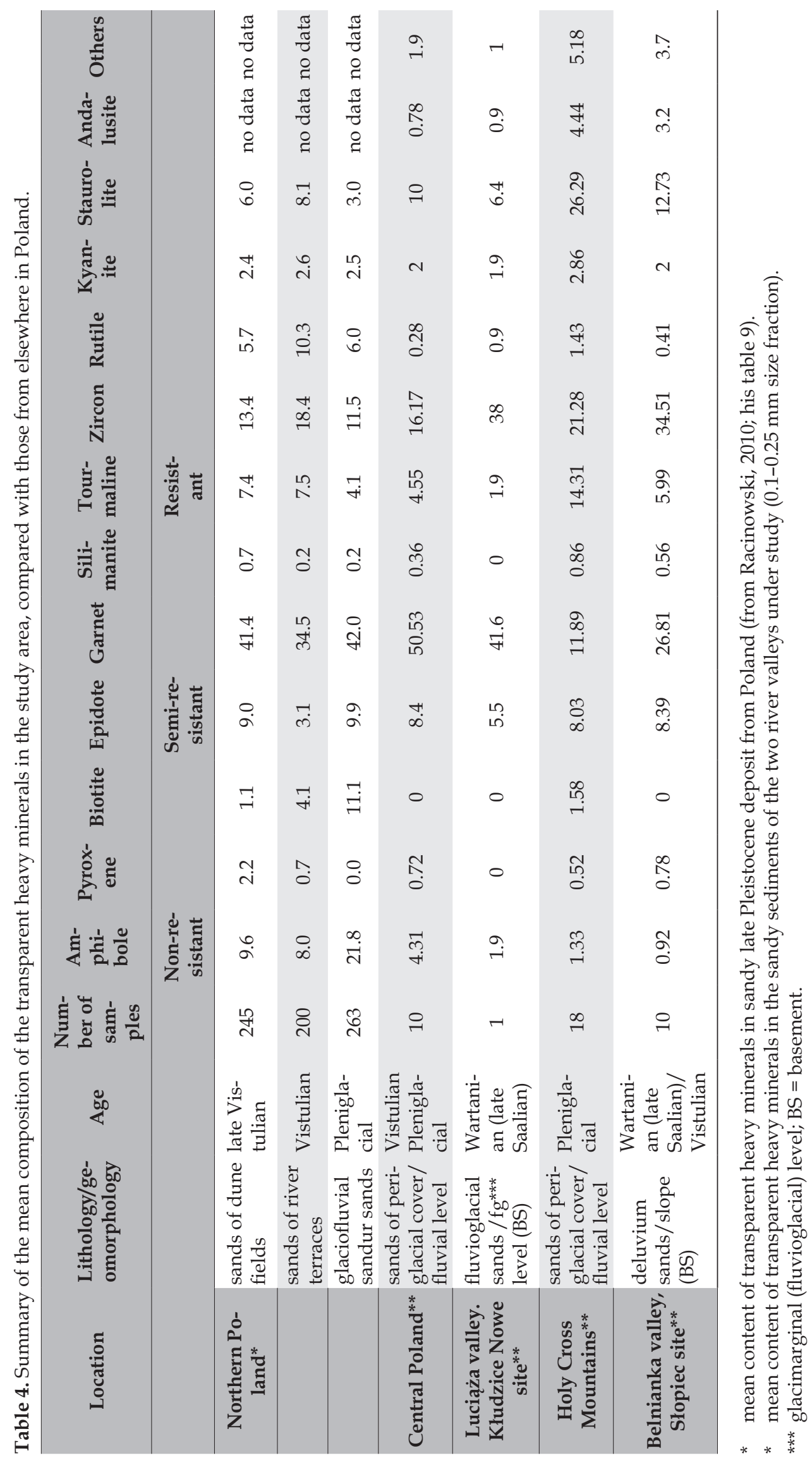


Luciąża valley are dominated by minerals with an average resistance to chemical weathering (42.7-72.6\%), especially garnet (30.2-65.2\%), with a significant proportion of resistant minerals (22.5-50\%) (Table 2; Figs 4, 6). The most important are zircon $(8.2-38 \%)$, staurolite (6.4-15.4\%), epidote (5.1-12.1\%), amphibole (1.3-5.8\%; $16.6 \%$ in sample \#7), tourmaline (1.4-6.7\%) and kyanite (0.9-3.6\%). Non-resistant minerals are much less frequent (1.7-18\%). Biotite and chlorite have not been separated. Rutile, andalusite and sillimanite occur in minor amounts, up to $1 \%$. The sediments of the Pleniglacial fluvial level above the erosional contact with the Wartanian fluvioglacial deposits contain more amphibole, pyroxene, epidote, garnet, tourmaline and staurolite than the older ones.

The large percentage of garnet, which is medium-resistant to mechanical destruction, suggests a fluvial environment (cf. Morton et al., 2013), in which relative enrichment of garnet took place. However, given the strong aeolian influence (mat and roundness), it seems that this relative enrichment of garnet took place not only in a fluvial environment, but also - and perhaps primarily - in an aeolian one. This is supported by the lack of micas, which due to their habit - form thin plates and which have a low specific weight. It thus seems that the sediments were repeatedly reworked and affected by wind (Barczuk \& Mycielska-Dowgiałło, 2001). These sands are enriched in heavy minerals with a higher hydraulic equivalent and a larger resistance to weathering (Racinowski, 2008).

Among all samples from Kłudzice, sample \#7 (3.25 m depth) in particular shows an interesting heavy-mineral assemblage (Table 2 ). It has the largest proportion of amphibole and pyroxene $(18 \%)$, epidote $(12.2 \%)$, minerals that are highly resistant to chemical weathering and mechanical abrasion, whereas the proportion of garnet is the smallest $(30.2 \%)$. Structural and textural (grain size) analysis of the sediments indicates a strong erosion, due to a higher energy level, resulting in the supply of 'fresh' fluvial material, with a different mineral composition. This explains the highest value (21.0) of the weathering index for this sample.
The lower this index, the larger the proportion of resistant materials, i.e. the more favourable the conditions for selective reworking of the fluvial deposits and for depriving them of less resistant minerals.

The vertical succession of the sediments shows cycles in the weathering index (1.79$21 \%$ ), which suggests varying energy levels of the fluvial environment.

Comparison of the assemblages of the transparent heavy minerals of the Luciąża sediments with those elaborated for fluvial and fluvioglacial deposits of Poland as a whole (Racinowski, 2010) (Table 4, Fig. 5) indicates a strong similarity in the type of assemblages of the minerals and their quantitative characteristics. Intense aeolian processes occurred all over the Polish Lowlands, in all morphogenetic zones, and this resulted in relative enrichment of garnet (cf. Barczuk \& Mycielska-Dowgiałło, 2001).

\subsection{Heavy minerals from the Pleniglacial fluvial deposits in the Belnianka valley}

The heavy-mineral assemblages of the middle Pleniglacial sediments in the Belnianka valley at Słopiec are different, but homogeneous, which is indicative of sedimentation within a short time. The assemblages are dominated by minerals resistant to mechanical destruction (58.6-82.6\%), mainly staurolite (14.8-35.6\%), zircon (12.4-31.3\%), tourmaline (6.5-24.5\%), with a much lower content of andalusite (1.1$6.7 \%)$, kyanite $(1.1-7.2 \%)$ and rutile $(0-3.3 \%)$ (Table 3, Figs 5, 6). There is a comparatively large proportion of garnet $(6.6-25.8 \%)$ and semi-resistant minerals $(12.2-32.6 \%$, consisting of $1.1-6.7 \%$ andalusite and $4.3-10.3 \%$ epidote). Modestly unstable minerals (0.1-7.9\%) are represented by biotite $(0-3.3 \%)$, amphibole $(0-6.3 \%)$ and pyroxene $(0-2.2 \%)$. The mineral compositions within the nearly 10-m level of the sediments is homogeneous and suggests a strongly weathered source of fluvial deposits, which is confirmed by the weathering-index values, which range from 0.1 to 3.06 .

Regarding vertical changes of the heavy-mineral composition in the studied profile, a slight increase in garnets, accompanied 
by a decrease in amphibole, is present in its subaerial part (from $3 \mathrm{~m}$ ). This is presumably an aeolian effect, helped by pedogenic processes that relatively enriched the deposits in garnet and impoverished the amphibole content.

The assemblages are comparable to those of the Wartanian slope deposits of the Bielinskie range in the Holy Cross Mountains (Ludwikowska-Kędzia, 2007) (Table 4, Figs 5, 6). The assemblages in these deposits must be inherited from pre-Quaternary, Palaeogene-Neogene, or even older, Palaeozoic or Mesozoic rocks according to Racinowski (1995). The heavy-mineral assemblages, with a dominance of zircon, tourmaline, staurolite, rutile and kyanite may be taken as typical of the pre-Quaternary, especially from the highland zone. This is supported by mineralogical studies of the Palaeozoic bedrock in the Holy Cross Mountains (Radziszewski, 1928; Kosmowska-Ceranowicz, 1979).

A comparison of the structure of the transparent heavy minerals from the fluvial deposits in the Belnianka valley with the fluvial and fluvioglacial deposits of Poland in general (Racinowski, 2010) (Table 4, Fig. 6) indicates that the Pleniglacial deposits do not show any significant qualitative differences. In contrast, some quantitative similarities are present in the heavy-mineral assemblages, mainly in the form of the low percentages of amphibole, pyroxene, biotite and garnet, and the high percentages of zircon, staurolite and tourmaline. This suggests that both the source deposits and the Pleniglacial deposits underwent intensive and/or persistent chemical weathering and numerous sedimentation/erosion cycles.

\section{Conclusions}

Analysis of the heavy minerals from representative profiles of the Pleniglacial sediments in the Luciąża and Belnianka valleys show that the differences in their assemblages are largely controlled by the differences in lithology of both areas. In the Luciąża valley, the structure of the heavy minerals diverse, which is typical for primary Quaternary fluvioglacial deposits in the Polish Lowlands province. In contrast, the heavy-mineral assemblages from the Belnianka valley, representing the Highlands Belt province, are clearly dominated by minerals that are resistant to mechanical destruction, which were, apart from the much larger amounts of grains derived from a local fluvial source, inherited from the Palaeozoic, Mesozoic and Palaeogene-Neogene substratum, and which underwent intensive chemical weathering under periglacial conditions. This indicates a direct influence of the Pleistocene ice sheets on the valley system in the central part of the Holy Cross Mountains, but this influence was far too small to obscure the local mineralogical background.

In both valleys, the heavy-mineral assemblages in the fresh Pleniglacial valley levels record aeolian influence in the form of a relative enrichment in garnet. This must be ascribed to intensive aeolian action, rather than to long-lived aeolian activity. The aeolisation in both valleys took place in a periglacial environment, but was strongest close to the active front of the ice sheet; hence the larger proportion of garnet in the sediments of the Luciąża valley, and hence also the higher concentration of matt grains in this valley. The increase in aeolian activity in the Belnianka valley may have been due to tectonic activity along a Palaeozoic fault: elevation of the area caused lowering of the groundwater level, and consequently a dryer sedimentary surface, making the surficial sediments more prone to intensive aeolian influence (Jaśkowski, 1999).

\section{Acknowledgements}

The authors would like to thank J. Bugajska for the analysis of the heavy minerals.

\section{References}

Barczuk, A. \& Mycielska-Dowgiałło, E., 2001. Znaczenie składu mineralnego osadów dla rozpoznawania obecności procesów eolicznych [The importance of the mineral composition of sediments for the recognition of aeolian processes]. [In:] E. Mycielska-Dowgiałło (Ed.): Eolizacja osadów jako wskaźnik stratygraficzny czwartorzędu [Aeolisation of deposits as a Quaternary stratigra- 
phical indicator]. WGiSR UW, Warsaw University, Warszawa, 39-42.

Bateman, R.M. \& Catt, J.A., 2007. Provenance and palaeoenvironmental interpretation of superficial deposits, with particular reference to post-depositional modification of heavy mineral assemblages. [In:] M.A. Mange \& D.T. Wright (Eds): Heavy minerals in use. Developments in Sedimentology 58, 151-188.

Cordier, S., Harmand, D., Losson, B. \& Beiner, M., 2004. Alluviation in the Meurthe and Moselle valleys (eastern Paris Basin, France): lithological contribution to the study of the Moselle capture and Pleistocene climatic fluctuations. Quaternaire 15, 65-76.

Gilewska, S., 1991. Rzeźba [Relief]. [In:] L. Starkel (Ed.): Geografia Polski - środowisko przyrodnicze [Geography of Poland - natural environment]. Wydawnictwo Naukowe PWN, Warszawa, 248-296.

Jaśkowski, B., 1999. Związek późnovistuliańskich procesów wydmotwórczych w regionie świętokrzyskim z neotektoniczną aktywnością podłoża [The interrelationship between late Vistulian dune-forming processes and neotectonics in a basement complex of the Holy Cross Mountains region]. Przeglad Geologiczny 74, 1032-1038.

Kosmowska-Ceranowicz, B., 1979. Zmienność litologiczna i pochodzenie okruchowych osadów trzeciorzędowych wybranych rejonów północnej i środkowej Polski w świetle wyników analizy przezroczystych minerałów ciężkich [Lithological variability and origin of the Tertiary clastic sediments in some regions of northern and central Poland in the context of the analysis of the transparent heavy minerals]. Prace $\mathrm{Mu}$ zeum Ziemi 30, 1-68.

Ludwikowska-Kędzia, M., 2000. Ewolucja środkowego odcinka doliny rzeki Belnianki w późnym glacjale i holocenie [Evolution of the middle part of the Belnianka River valley in the Late Glacial and Holocene]. Wydawnictwo Akademickie Dialog, Warsaw, 180 pp.

Ludwikowska-Kędzia, M., 2007. Wybrane cechy strukturalne i teksturalne deluwiów Pasma Bielińskiego w rejonie Huty Starej Koszary i ich wymowa paleogeograficzna [Some structural and textural features of slope deposits of the Bielińskie range in the Huta Starej Koszary area and its palaeogeography]. [In:] M. Ludwikowska-Kędzia \& M. Wiatrak (Eds): Różnorodność środowiska geograficznego Gór Świętokrzyskich w badaniach regionalnych [Diversity of the Holy Cross Mountains geography in regional investigations]. Inst. Geogr. Akad. Świętokrzyskiej w Kielcach, 95-113.

Ludwikowska-Kędzia, M., 2013. The composition of transparent heavy minerals in Quaternary sediments of the Kielce-Łagów valley (Holy Cross Mountains, Poland). Geologos 19 (this issue), 95-129.

Łyczewska, J., 1971. Czwartorzęd regionu świętokrzyskiego. Stratygrafia kenozoiku Gór Świętokrzyskich i ich obrzeżenia [Quaternary of the Holy Cross Mountains region. Cenozoic stratigraphy of the Holy Cross Mountains and its margin]. Prace Instytutu Geologicznego 42, 5-86.

Marcinkowski, B. \& Mycielska-Dowgiałło, E., 2013. Heavy-mineral analysis in Polish investigations of
Quaternary deposits: a review. Geologos 19 (this issue), 5-23.

Marks, L., 2011. Quaternary glaciations in Poland. Developments in Quaternary Science 15, 299-303.

Miall, A.D., 1978. Lithofacies types and vertical profile models in braided river deposits: a summary. Fluvial sedimentology. Canadian Society of Petroleum Geologists, Memoir 5, 597-604.

Miall, A.D., 1985. Architectural-element analysis: new method of facies analysis applied to fluvial deposits. Earth-Science Reviews 22, 261-308.

Morton, A., Hounslow, M.W. \& Frei, D., 2013. Heavy-mineral, mineral-chemical and zircon-age constraints on the provenance of Triassic sandstones from the Devon coast, southern Britain. Geologos 19 (this issue), 67-85.

Mycielska-Dowgiałło, E., 1995. Wybrane cechy teksturalne osadów i ich wartość interpretacyjna [Some textural features and their possible interpretations]. [In:] E. Mycielska-Dowgiałło \& J. Rutkowski (Eds): Badania osadów czwartorzędowych. Wybrane metody i interpretacja wyników [Investigation of Quaternary deposits. Some methods and interpretation of the results]. Warsaw University, Warszawa, 29-105.

Mycielska-Dowgiałło, E. (Ed.), 2001. Eolizacja osadów jako wskaźnik stratygraficzny czwartorzędu [Aeolisation of sediments as an indicator of Quaternary stratigraphy]. Warsaw University, Warszawa, 141 pp.

Mycielska-Dowgiałło, E., 2007. Metody badań cech teksturalnych osadów klastycznych i wartość interpretacyjna wyników [Methods for the investigation of the textural features of clastic deposits and the significance of the interpretations]. [In:] E. Mycielska-Dowgiałło \& E. Rutkowski (Eds): Badania cech teksturalnych osadów czwartorzędowych $i$ wybrane metody oznaczania ich wieku [Investigation of the textural features of Quaternary sediments and some dating methods]. The Family Alliance School of Higher Education Press, Warsaw, 95-180.

Racinowski, R., 1995. Analiza minerałów ciężkich w badaniach osadów czwartorzędowych Polski [Analysis of heavy minerals in studies of Quaternary sediments of Poland]. [In:] E. Mycielska-Dowgiałło \& J. Rutkowski (Eds): Badania osadów czwartorzędowych [Investigation of Quaternary sediments]. WGiSR, Warsaw University, Warszawa, 151-166.

Racinowski, R., 2008. Znaczenie analizy minerałów ciężkich w badaniach osadów czwartorzędowych Polski [The significance of heavy-minerals analysis for the study of Quaternary deposits in Poland]. Annales Universitatis Mariae Curie-Skłodowska B 63, 7-44.

Racinowski, R., 2010. Główne przeźroczyste minerały ciężkie w osadach czwartorzędowych Polski [Main transparent heavy minerals in Quaternary deposits of Poland]. Biuletyn Państwowego Instytutu Geologicznego 438, 99-106.

Racinowski, R. \& Rzechowski, J., 1969. Minerały ciężkie w glinach zwałowych Polski środkowej [Heavy minerals in glacial tills of central Poland]. Kwartalnik Geologiczny 13, 479-490.

Radziszewski, P., 1928. Przyczynek do petrografii dolnego kambru we wschodniej części Gór Świętokrzys- 
kich [Contribution to the petrography of the lower Cambrian in the eastern part of the Holy Cross Mountains]. Sprawozdania Państwowego Instytutu Geologicznegol 4, 500-532.

Schneiderman, J.S. \& Chen, Z., 2007. Interpretation of Quaternary tectonic and environmental change using heavy minerals of the Yangtze delta plain. [In:] M.A. Mange \& D.T. Wright (Eds): Heavy minerals in use. Developments in Sedimentology 58, 607-620.

Starkel, L., 2008. Paleogeograficzne korzenie współczesnej rzeźby Polski [Palaeogeographic roots of the present-day relief of Poland]. [In:] L. Starkel, A. Kostrzewski, A. Kotarba \& K. Krzemień (Eds): Wspótczesne przemiany rzeźby Polski [Recent transformation of the Polish relief]. Instytut Geografii i Gospodarki Przestrzennej Uniwersytetu Jagiellońskiego, Kraków, 13-20.

Thamo-Bozso, E. \& Kovacs, L.O., 2007. Evolution of Quaternary to modern fluvial network in the mid-Hungarian plain, indicated by heavy mineral distributions and statistical analysis of heavy mineral data. [In:] M.A. Mange \& D.T. Wright (Eds): Heavy minerals in use. Developments in Sedimentology 58, 491-514.

Turkowska, K., 2006. Geomorfologia regionu łódzkiego [Geomorphology of the Łódź region]. University of Łódź, Łódź, 236 pp.

van Loon, A.J., 1972-1973. "Habitus" of some heavy minerals from the Tertiary of Southern Limburg (The Netherlands). Mededelingen van de Rijks Geologische Dienst, Nieuwe Serie 23, 39-67.

Van Loon, A.J., 2009. Soft-sediment deformation structures in siliciclastic sediments: an overview. Geologos 15, 3-55.

Van Loon, A.J. \& Mange, M.A., 2007. “In situ” dissolution of heavy minerals through extreme weathering, and the application of the surviving assemblages and their dissolution characteristics to correlation of Dutch and German silver sands. [In]: M.A. Mange \& D.T. Wright (Eds): Heavy minerals in use. Developments in Sedimentology 58, 189-213.

Wachecka-Kotkowska, L., 2004. Ewolucja doliny Luciąży - uwarunkowania klimatyczne a lokalne [Evolution of the Luciąża river valley - climatic and local conditions]. Acta Geographica Lodzensia 86, 1-161.

Wachecka-Kotkowska, L., 2006. Relacje między ukształtowaniem współczesnej powierzchni Równiny Piotrkowskiej i Wzgórz Radomszczańskich z planem strukturalnym podłoża [Relations between the relief of the Piotrków Plateau and the Radomsko Hills with the substratum of the structural plan]. [In:] P. Czubla \& W. Mizerski (Eds): Geologia regionu tódzkiego i obszarów przylegtych [Geology of the Łódź region and its neighbourhood]. Przeszłość dla przyszłości. University of Łódź, Łódź, 33-46.
Wachecka-Kotkowska, L., 2007. Wybrane cechy teksturalne osadów plejstoceńskich i holoceńskich budujących powierzchnię Równiny Piotrkowskiej i Wzgórz Radomszczańskich [Some textural features of the Pleistocene and Holocene surface sediments of the Piotrków Plateau and the Radomsko Hills]. [In:] Rekonstrukcja dynamiki procesów geomorfologicznych - formy rzeźby i osady [Reconstruction of geomorphological processes - relief and deposits]. Warsaw University, Komitet Badań Czwartorzędu PAN, Warszawa, 411-417.

Wachecka-Kotkowska, L. \& Ludwikowska-Kędzia, M., 2007. Plenivistuliański poziom wysoki w dolinach rzek Luciąży (Równina Piotrkowska/Wzgórza Radomszczańskie) i Belnianki (Góry Świętokrzyskie). Porównanie cech strukturalnych i teksturalnych osadów [The Plenivistulian level in the Luciąża (Piotrków Plateau/Radomsko Hills) and Belnianka (Holy Cross Mountains) river valleys. Comparison of the structural and textural features of the sediments]. Acta Geographica Lodziensia 93, 107-132.

Weckwerth, P. \& Chabowski, M., 2013. Heavy minerals as a tool to reconstruct river activity during the Weichselian glaciation (Torun Basin, Poland). Geologos 19 (this issue), 25-46.

Weltje, G.J. \& von Eynatten, H., 2004. Quantitative provenance analysis of sediments: review and outlook. Sedimentary Geology 171, 1-11.

Woronko, B. (Ed.), 2012. Grain-size analysis: methods and significance. Geologos 17(4), 187-238.

Woronko, B., Rychel, J., Karasiewicz, M.T., Ber, A., Krzywicki, T., Marks, L. \& Pochocka-Szwarc, K., 2013. Heavy and light minerals as a tool for reconstruction of depositional environments: an example from the Jałówka site (northern Podlasie region, NE Poland). Geologos 19 (this issue), 47-66.

Wróblewski, T., 1977. Rzeźba Gór Świętokrzyskich [Relief of the Holy Cross Mountains]. Rocznik Świętokrzyski KTN 5, 9-22.

Yang, S., Wang, Z., Guo, Y., Li, C. \& Cai, L., 2009. Heavy mineral compositions of the Changjiang (Yangtze River) sediments and their provenance-tracing implication. Journal of Asian Earth Sciences 35, 56-65.

Zieliński, T. \& Pisarska-Jamroży, M., 2012. Jakie cechy litologiczne warto kodować, a jakie nie? [Which features of deposits should be included in codes and which not?]. Przeglad Geologiczny 60, 387-397.

Manuscript received: 6 November 2012 Revision accepted: 2 March 2013 